\title{
Coastal Land Uses for Tourism in Sri Lanka: Conflicts and Planning Efforts
}

\section{Herath Madana Bandara ${ }^{1}$ and Iraj Ratnayake ${ }^{2}$}

${ }^{1}$ University of Ilorin, Nigeria.

${ }^{2}$ Department of Tourism Management, Faculty of Management Studies, Sabaragamuwa University of Sri Lanka.iraj@mgt.sab.ac.lk

\begin{abstract}
Tourism in Sri Lanka involves mainly activities in the beach area. From the inception of formal tourism, tourist product development, conservation, preservation and protection have been given a high priority through land zoning and tourism legislation. National Holiday Resorts were established mainly in coastal areas following the recommendations of the first master plan and continued the same in similar subsequent planning attempts. This paper evaluates those planning efforts and observes existing land conflicts. The planning efforts were not worked as expected and conflicts have arisen due to the lack of funding, implementation, co-operation, monitoring and evaluation. The article hypothesises that land use planning for tourism requires total co-operation of the state sector, private sector organisations and the local community.
\end{abstract}

Keywords: Coastal Tourism, Conservation and Preservation, Land Zoning, National Holiday Resorts, Tourism Legislation

\section{Introduction}

Tourism has come to stay as a significant sector in the national economy of Sri Lanka. Overall contribution of tourism to the national economy is about 2 percent of Gross Domestic Product (GDP). It is the sixth largest foreign exchange earner in the balance of payments in Sri Lanka (Sri Lanka Tourism Development Authority, 2011). Since it has been accepted as a development option in the country, maximisation of economic benefits such as foreign exchange, employment, government revenue, etc., is given priority by the government (Samaranayake, 1998). In order to achieve this, it is needed to support tourist attractions and facilities and to attract a best possible number of tourists. Therefore, product development is considered as a major tourism development strategy (UNDP/WTO, 1993). As product development activities essentially create land use conflicts it compulsorily involves land use planning.

Sri Lanka covers about 6.56 million hectares, of which 1.8 percent includes 
inland waters (Somasekaram, 1997). A rough indicator of demands on land resources can be appreciated by considering the land-man ratio. In 1871, when Sri Lanka contained only 2.4 million people, about 2.7 hectares were available per person. Today at about 17 million, land has decreased to 0.38 hectares per person (NARESA, 1991). The demand for land has brought the land-man ratio below minimum levels in Sri Lanka and led to loss of forest cover and loss of bio-diversity. By 2011, the land-man ratio has been decreased further to 0.32 hectares showing the pressure on land-use decision.

Clearing up the forests for plantation agriculture was the greatest change that took place in the $19^{\text {th }}$ century (Madduma Bandara, 1998). Large multipurpose schemes, involving the construction of reservoirs for irrigated agriculture and power generation and settling people in these areas by clearing the forests, are other land use changes that have occurred during the 20th century. Further deforestation is inevitable as land is needed for future agricultural development and other uses. The Land Commission report (Government of Sri Lanka, 1987a) indicated that nearly two million hectares of land with potential for agricultural development remain unutilised. The estimate includes land under forests with good soils under some wildlife reserves, which are needed for conservation purposes. This deforestation adversely affects long-term protection of reservoirs, food and fibre for neighbouring villages, and other forest uses, including protection of biological diversity. In view of the serious ecological implications, a further reduction in the forest cover cannot be tolerated in any circumstances.

Still nearly 80 percent of the total land area of the island is under the ultimate ownership of the government. The country with a policy of having such a monopoly in the government has its positive as well as negative aspects. It has been argued that this has facilitated the process of creating large-scale land settlement schemes in the Dry Zone. It has also been claimed that the Crown Land Encroach Ordinance (Government of Ceylon, 1840) has provided the legal basis for the eviction of unlawful occupants from state lands. Very importantly, this gives provisions for allocation of government land reserves for other land use needs such as tourism.

The negative impacts of having such a state monopoly seem to far outweigh the benefits mentioned above. With increasing population, rural people have been compelled to encroach on state lands through sheer necessity. Adding to this challenge are the economic, social and environmental impacts of continued degradation of Sri Lanka's land resources from misuse and overexploitation. Therefore, the clearing of lands for other uses such as tourism is a big problem. Moreover, competition for land among various users including tourism will, inevitably, become a more pressing problem. 
Tourism in Sri Lanka, from a land use perspective, involves mainly activities in the beach areas, cultural heritage sites and wildlife matters. It is evident that the usual round tour includes a stay in a beach-fronted hotel and tours to the Ancient Cities of Kandy, Sigiriya, Polonnaruwa, and Anuradapura and to the wildlife reserves of Yala, Udawalawe, and Wilpattu. However, the popularity of the beach holiday among the predominantly Western European winter tourists is evident from the high occupancies in the beach-oriented hotels in winter. Approximately half of the average duration of stay of a tourist (7-8 days) is spent near the beach. Some 1000 miles of coastal area in the country are extensively utilised for tourism product development. This accounts for the large cluster developments of hotel facilities by the beach (Ranasingha, 1997). About 75 percent of the graded hotels in Sri Lanka and 80 percent of the hotel rooms are located in coastal areas. Most of the beach areas in Sri Lanka are densely populated and engaged in different activities such as fisheries, coconut fibre, slaked lime, etc. Therefore tourism activity has seemingly come into conflict with industries that compete with it for the use of coastal resources. For example, coconut lands are increasingly being converted to other uses such as tourism industry. Thus, exploitation of land for tourism activities creates sociological problems such as displacement of the local community, landlines, loss of traditional way of life, obstruction of traditional access to the beach, etc. Land use planning and resource allocation for tourism are therefore an additional challenge.

Traditionally, agriculture was the main concern of Crown Land management decision making in Sri Lanka. Sri Lanka has experimented with different methods of land reform in response to socio-economic and political demands; however, little progress has been made in comprehensive land use planning and implementation (NARESA, 1991).

Unlike traditional activities such as agriculture and fisheries, tourism is an additional pressure for Sri Lanka's land. Thus, land use for tourism requires careful planning as it inevitably conflicts with other traditional land uses. The setting up of tourist facilities is, therefore, conditional upon prevailing national land use systems and laws. Allocation of Lands for tourism was started by the government from 1967, following the recommendations of the first tourism master plan (Harris, Kerr, Foster and Company, 1967). Since then, several steps have been taken to avoid land conflicts and adverse effects of land uses of tourism, met with limited success.

This article focuses to examine the planning efforts and issues of coastal land use for tourism in Sri Lanka. The article explores land use policies, strategies, and the effects of land uses for tourism. It further analyses the reasons for land conflicts and adverse effects, which help decision makers in implementing acceptable solutions. 


\section{Conceptual Framework}

In any country, competition from different land uses for the same area of land often creates conflicts. Fishermen, for example, can be in conflict with tourists who wish to have access to their beach. The construction of new motorways may cause conflict with conservationists who wish to protect rural land areas. Thus, there is growing pressure from various land uses, including farming, forestry, military and quarrying, as well as tourism. Therefore how this resource is used, or land use, is a matter of fundamental importance.

Since tourism is accepted as a growth activity (Jenkins, 1994), product development is inevitable as a tourism development strategy that involves upgrading the existing attractions and product; diversifying the product range and expanding its capacity; and developing new circuits and product packages inland, including new tourist areas. These exercises essentially impact on the natural and social environment. Environmental protection and enhancement is increasingly important for the local population as well as influencing tourists' choice of destination.

Today, there is a great debate raging over the best way forward in developing tourism activities and the areas affected by them. Broadly and Cunningham (1994) have put forward a number of factors in favour of land use for tourist activities. Firstly, tourist resort status, which is nominated and reserved by the government only for tourism, would give legal protection in the area, thwarting any unplanned, unsightly, unsuitable developments within the site. Secondly, government investment would be available to provide upgraded visitor amenities, e.g. accommodation, leisure and visitor centres, tourist information, etc. Thirdly, improved communications including upgraded TV and radio, roads and rail links would be developed. Fourthly, the local environment, its flora and fauna and scenic beauty would be preserved for the nation and the future. Fifthly, local people would benefit from increased facilities and from jobs in tourism and therefore unemployment rates would fall. The local economy would be boosted. Sixthly, rural population would cease and communities would grow. Seventhly, the most sensitive areas would be protected - parts of these could be 'out of bounds' to preserve their beauty. Eighthly, a wide range of leisure activities would be provided for visitors - hill walking, sailing, fishing, golf, pony trekking - all giving jobs to locals.

Conversely, there are cases (McKercher, 1992; Williums, Penrose and Hawkes, 1998) against land use for tourism activities. Firstly, opening up of the tourist areas (National Resort status) would lead to many restrictions being placed upon local initiatives and existing farming, forestry and fish farming industries. Secondly, areas will benefit from investment in its infrastructure, industrial base and employment anyway. Thirdly, giving National Resort status 
would encourage even more visitors to the area, increasing existing problems of congestion, pollution, footpath erosion, and general disturbance to flora and fauna. Fourthly, local people would not necessarily benefit from national park status - 'holiday resort syndrome' would mean young locals moving away since many local houses would be bought by urban dwellers. Fifthly, the 'right of access' may be lost to areas - locals and some visitors would not readily accept restrictions to their movement. Sixthly, locals argue strongly that it is conservation (maintenance of the living landscape) and not preservation that is urgently required in the area. Seventhly, wide ranges of leisure activities already exist. Eighthly, local culture would be under threat for increased numbers of visitors. Thus National Park status will increase the problems for these areas - attracting even more visitors, fuelling local conflict over land use and encouraging the setting up of 'out of bound areas'. However, problems of rural access and protection will not go away as land is increasingly needed for leisure. Therefore, tourism product development strategy includes the need for a planned approach to land use and development.

Land use planning - the process of making recommendations regarding the allocation of space for a variety of human activities (SSSA, 1984) - is important for any country, for a number of reasons. First, land is finite or has physical limits and therefore land supply is inelastic. Second, population is continuing to grow and therefore the demand for land is increasing. Third, the maintenance and restoration of clean and pleasant environments are important social goals. Fourth, land use planning deals with social equity. In short, ecological environment, economic efficiency, technological progress and cultural consistency should be taken into account in any land use planning. A careful integration of these concerns leads to the new direction of development - increased growth and sustainable development.

In ecological terms, resource management is the allocation of resources in a manner that minimises environmental 'impairment'. To avoid abuse and overuse of resources, 'Environmental Impact Assessment' is rapidly used in developed countries as well as in developing countries. The ecological approach has been applied more widely in managing tourist assets such as national parks, forests and soils than other resources in developing countries. This has been because the management goals emphasise preservation and protection of plants, animals and soils in these areas. In game parks, the ecological approach is used to monitor environmental quality change and to assess the environmental impacts of proposed and existing developments.

In economic terms, the objective of resource allocation is to achieve economic efficiency by minimising production costs and maximising monetary profits. There are limitations to this approach because some goods such as visual beauty, unique ecological habitat and historical monuments are subjective and 
personal in their value and cannot easily be evaluated in the market place. In the economic approach, 'Benefit-cost analysis' is the most commonly used technique of resource allocation because its desired objective is to choose the lowest cost alternative from a number of alternatives designed to meet the objectives (Ciriacy-Wantrup, 1971).

Technological approach is closely associated with economic approach. It means the increase of productivity in the same piece of land by using improved techniques. It leads to intensive use of land instead of extensive use.

The ethnological approach offers cultural consistency as a criterion for resource allocation. This is an important consideration in developing countries where conflicts between competing tribal interests often result in costly failure and abandonment of government projects. In order to avoid conflicts with politics, law, tradition and institutional arrangements it is important to undertake 'social impact assessment'. An approach to land use planning, as Redclift and Sage (1996) suggest, requires a balance to be struck between what can be achieved locally, through the participation of local communities, and the removal of structural policies, at the intersectoral, national and international level, that impact on the rural poor regardless of their individual commitments to better environmental management leading to sustainable development.

Many researchers (Gunton and Flynn, 1992; McKercher, 1992; Williums, Penrose and Hawkes, 1998) have examined 'integrated resource management' as a strategy in land use planning. Integrated resource management is a topdown decision making process with various forms of public consultation and with the creation of government institutional structures which encouraged a more integrated approach to resource management and land use strategy. This is meaningful as government expands the use of multi-party planning processes and consensus negotiation techniques among many of its publics. Gunton and Flynn (1992) saw mixed success of this approach and suggested a similar approach to more collective and shared planning which potentially would accommodate a wider set of values. This public participation approach involves transparent, carefully designed, well understood, and consistently applied public process. McKercher (1992) observed that future of the industry would be assured if a workable resource allocation system can be implemented that is adopted by all parties involved. Williums, Penrose and Hawkes, (1998) have applied Shared Decision Making Process (SDM) to assess the efficacy of the process from the perspective of tourism stakeholders who participated in the planning process. They offered recommendations to government as well as tourism sector organisations concerning the management of future public land use planning strategies designed to fully incorporate stakeholders into such processes. Thus, the literature suggests that integrated planning approach with all parties involved minimises the land use conflicts. 


\section{Methodology}

The research for this study involved a number of sequential phases. A comprehensive literature review was carried out in order to develop the conceptual framework. Organisational literature was reviewed to explore and become familiar with the historical and current land use pattern, strategies, organisational structure, regulations and legislation, etc., in Sri Lanka. As there was a wide range of issues and concepts, the researcher allowed the data to emerge rather than forcing it through preconceptions.

A field survey was conducted in Sri Lanka utilising in-depth interviews and direct observations. The main method of data collection of this research was in-depth unstructured interviews. This is for three reasons. Firstly, it is believed that in-depth interviews are the most effective route in order to gather an 'authentic' understanding of people's experiences (Strauss and Corbin, 1998). Secondly, the structure of these interviews is flexible and the restrictions minimal, being presented in the form of guides rather than rules (Sarantokos, 1998). Thirdly, the in-depth interview method is often conducted with small samples. The interviewees of this research were known, selective and small in number. The researcher used unstructured open-ended questions only. They were predominantly single interviews, questioning one person at a time. The question structure was not fixed allowing change of question order and addition of new questions where necessary. The interviews were conducted with different administrators from tourism-related ministries, departments, tourism organisations and the private sector as exploring their observations and opinions were useful to gain additional insight into the meaning of the interpretations. As most of the interviewees are well educated interviews were performed satisfactorily.

The observational method was used when other methods were not effective to observe certain issues such as environmental and social issues. As this method offers first-hand information without relying on the reports and others it is the most appropriate method by which to understand another culture. The researcher visited some popular tourist resorts in Sri Lanka mainly to observe social and environmental issues.

A systematic inductive process (Systematic Comparison of Phenomena) was applied to synthesise the data. This was accomplished by successive approximation of raw data or identification of main themes from interviews and observations. As Sarantakos (1998) explains, this method begins with some basic observations and the resulting assumptions about the existence of concepts. In this process, concepts were contrasted with empirical data and theories with empirical evidence. Temporary and conditional hypotheses were consequently developed and then further refined in a continuous process. These 
results were compared with the acknowledged influence of other authors' and the researcher's own pre-understanding and generalised meanings and causes. Therefore, this research approach was exploratory and qualitative, focusing on the macro setting and social interaction, describing reality as experienced by the respondents and employing methods of data collection and analysis that are non-quantitative.

\section{The Planning Efforts}

The planning efforts relating to coastal land use for tourism in Sri Lanka can be broadly categorised into two topics; land zoning, and conservation and preservation of coastal land. In each discussion, a detailed evaluation of relevant strategies and tourism legislation are included.

\section{Land Zoning}

Land zoning is a common practice in developing countries to help achieve the goal of preservation (Dieke, 1988). The coastal zoning, on the one hand, takes account of residential land for communities; lands for their regular source of livelihood; siting of high polluting industries away from tourism areas; scenic areas which should not be developed; and public access routes which should not be obstructed. On the other hand, through land zoning, land is available for developers or providers of tourist facilities on reasonable terms and with developed infrastructure. Thus, land zoning helps progressive tourism development and minimises some land conflicts.

In Sri Lanka, in order to help achieve the goal of preservation, National Holiday Resorts (NHR) were established by the Ceylon Tourist Board (CTB) following the recommendations of the first tourism master plan (Harris, Kerr, Foster, 1967). The CTB had powers of compulsory acquisition of land endowed by the Tourist Development Act. No. 14 of 1968 (Government of Ceylon, 1968), Chapter 1, Section 2, 'for the purpose of any tourist development project'. This has been continued in the present Tourism Act No. 42 of 2005. The development of parks can be considered to be within the meaning of 'tourist development'. The CTB identified the areas of Hendala, Bentota, Koggala, and Amaduwa in the West and South Coasts and Passikudah and Trincomalee in the East Coast for resort development using the sea beaches as attractions. The CTB would acquire land in proximity to an identified attraction and develop the infrastructure before offering plots of land on lease to hotel developers on very attractive terms. The CTB being owner of the land was able to impose terms and conditions governing norms of design, space utilisation and sublease. 
This land zoning was not appropriate, as the authorities had lost control over tourist facilities development in the coastal zone. With the availability of more generous incentives the capacity of active NHRs was filled with hotel constructions with little or no time lag, and facilities spilled over and spread outside the NHRs. This resulted in a haphazard construction of buildings and the development of unplanned resort areas. A majority of hotels have less than a 15-meter setback between buildings and the water line of sea.

The absence of proper planning resulted to the loss of visual amenity. For example, the principal motorway skirting the West and South Coasts from Puttalam in the north-west to Hambantota in the south has been constructed very close to the beach, leaving only a narrow strip of land between the beach and the road at many points. Most of these narrow strips of land have been used for hotel construction because of the ready access to the beach. The result is the total obliteration of the view of the sea from the motorway at many scenic locations. In addition to loss of visual amenity, loss of tree and other vegetation cover makes coastal areas more prone to erosion.

A further result of construction close to the beach has been extensive sea erosion during the rainy season and high tides. Erosion has been experienced at Hikkaduwa, Bentota, Beruwala, Negombo and Waikkal, at or near tourist resorts. Thus, incremental unplanned growth has led to environmental problems. This partly attributed to lack of monitoring the projects and evaluation.

In all cluster developments by the beach, there are no centrally planned waste disposal systems (Senevirathna, 1994). It must be mentioned that centralised disposal systems have not been planned even for the NHRs established by the CTB. Centralised waste disposal systems have not been installed at any of the developed hotel clusters. Each unit has been allowed to design and install its own system, resulting in overflow of soakage pits owing to the high water table and the low absorption capacity of beach-side land. The pollution so caused may destroy the very resource that attracted tourists to these areas. Thus, land zoning in Sri Lanka is environmentally and ecologically not appropriate.

The unplanned developments are due to a number of reasons. Firstly, land supply of tourism does not meet the demand for land. As Senevirathna (1994) observes, some of those proposed NHRs were not implemented due to political, technical or financial reasons. The Tricomalee Resort Development Plan has yet to be implemented although the required land for the purpose has been vested with the CTB. Some proposed NHRs were developed as a resort with major hotel operations, some of which were vandalised during the period of unrest. For example, three hotels have been located in Passikudah, having developed the full infrastructure; however these are inoperative today due to 
vandalism. A 1000-acre land area in the Koddiyar bay was surveyed and acquired by the CTB for a major resort development with 1850 hotel rooms, marina and golf links, but the implementation has been delayed owing to the security situation.

Secondly, with the exception of Benthota and Passikudah there have been no purpose-built and planned beach resorts in Sri Lanka. For instance, while Bentota and Passikudah were established as fully-fledged resorts with an on-site resort administration, plots of land in the Koggala resort were leased without any service facilities being provided. In Hendala, private developers have established hotels without any inducement from the government to locate hotels there. The lack of state funds is among the many reasons for this.

Thirdly, the zoning plan for tourism development on the coastal belt has been prepared without total co-operation of all parties such as the CTB, the Coastal Conservation Department (CCD), the Department of Wildlife Conservation, the Ministry of Fisheries, the Surveyor General's Department, the Urban Development Authority (UDA), the Ministry of Local Government, Provincial Councils, tourism industry stakeholders and the local community. The plan divided the coastal belt of the island into segments and prescribed limitations to development where applicable, taking into consideration the competing uses of the beach. The plan, however, did not identify sites recommended for development at a micro-level. Implementation of recommendations was slowed or impossible as a legal force and administrative arrangement and cooperation were unavailable (Senevirathna, 1994).

In order to vest the CTB with more powers to control the development of facilities the Tourist Development (amendment) Act No.2 of 1987 (Government of Sri Lanka, 1987b) was passed. In terms of this Act, a designated area could be declared as a 'Tourist Development Area' in its boundaries by government gazette notification if the board considered it necessary to exercise control over tourist facilities in that area. Developers or providers of any tourist service or facility in such areas are required to register with the board. At this stage stipulations can be made with regard to planning requirements or standards. However, control over the siting of tourist facilities has never been very effective. On the one hand, the CTB's power to control the location, design and space utilisation by hotel developers is limited. On the other hand, the establishment of NHRs with complete infrastructure requires substantial capital investment by the state. The government would assign low priority to such investments.

The current master plan has suggested that the government-specifically the CTB, UDA, CCD and Local Government Authorities should proceed with the task of identifying land areas suitable for the construction of tourist facilities. 
Both the touristic value and also environmental stability must be taken into account in selecting such sites. If the incentives are specific to the users of these lands, the government will be able to encourage the siting of tourist facilities in desirable locations. It will also be possible to assess the pace of development and its magnitude reasonably well. However, development of hotels in Unawatuna resort area, which is selected as a development area by the current master plan, is opposed by powerful parties including local community and environmental friendly organisations, as it would create environmental problems and also cultural degradation (Bandara, 2000). This implies that zone planning in Sri Lanka is still has problems.

\section{Conservation and Preservation of Coastal Land}

There are coastal lands both in the development areas and the non-development areas, which would be aesthetically and environmentally desirable to conserve. If all or most of the narrow strips of land are maintained free of development giving a view of the sea, the drive along the coast would be immeasurably more pleasant both for tourists and local residents. The value of the beach as a tourism asset could then be sustained over a longer period of time. Therefore the conservation strategy is part and parcel of product development.

Preservation and conservation were major concerns of land zoning in the late 1960s in Sri Lanka. However, as discussed earlier, environmental factors did not receive the priority they deserved. The intensive construction of tourist facilities too close to the beach has created problems of access and beach stability.

The CCD has been given the specific mandate of regulating and controlling activities in the coastal zone and developing management plans for the zone (Coast Conservation Department, 1990). It has authority over all activities that take place within its mandated area of 300 meters from the high tide mark. One major area, which comes within the regulatory control of CCD, is hotel development within the coastal zone and the discharge of hotel effluent into the sea. Furthermore, coral mining activities, which deplete the beautiful undersea coral gardens and marine life are prohibited by law. The CCD will permit development of tourist hotels within the coastal zone in the approved locations and in accordance with the guidelines co-operatively developed by the CCD, the CTB, and the UDA. Where demolition is feasible, the Coast Conservation Act, Part v. Section 42, empowers the CCD to demolish structures constructed after 1981. In terms of section 28A of the UDA law, any on-going or completed development activity in a 'development area' can be stopped and all structures already completed caused to be demolished or altered. 
After establishing the Central Environmental Authority (CEA) under an act of parliament, the National Environmental Act, No. 47 of 1980 (Government of Sri Lanka, 1980), Environmental Impact Assessment for tourist development projects has been made mandatory by mutual arrangement between the CTB and the CEA. The CEA has being carrying out the function of defining Environmental Standards and framing and putting into action various regulations required for the proper execution of its functions. The regulations include those for protection and quality, procedure for approval of projects, etc.

Environmental Impact Assessments (EIA) are required for any new hotels or tourism resorts of over 40 rooms and resort areas. At present the prospective developer is required to submit the scheme to the CTB for approval. If approved, the proposal is then passed to the CEA and, if appropriate, to the CCD for approval. The EIA criteria are specified at this stage. Further the approval may be granted in concurrence with the UDA, CCD and the Local Government Authority so that planning requirements specified by these authorities are also observed. These legal provisions for conservation of the coastal environment are satisfactory.

Although there are legal provisions for conservation and preservation of the coastal land, the powers of the authorities to control facilities development are inadequate. Regulation of development is achieved only by means of incentives to comply with guidelines prescribed by the CTB rather than by legal compulsion (Senevirathna, 1994). The legal provisions cannot be used to evict residents on coastal land engaged in fishing or other economic activity. Obviously, it is also not possible to demolish that any of the large and medium sized hotels already constructed with approval by several state authorities, as considerable private investment has gone into the plant. Thus practicability of laws is sometimes questionable.

The economics of conservation is also a barrier to the relevant authorities wishing to implement conservation tools (Senevirathna, 1994). There are two main cost elements in the implementation of the proposal to conserve undeveloped coastal land: compensation for acquisition of freehold property on private lands; and expenditure on development of parks and recreation areas on conserved coastal lands. Furthermore, land issues in Sri Lanka are usually politically sensitive. The result is that political decisions overshadow the legislation. For example, some of the restricted areas are opened up for development on the recommendation of the Minister-in-charge of the subject of Tourism. Thus, with shortage of funds, land disputes and politically influenced issues, the legal provisions for conservation and preservation in Sri Lanka are often ineffective. 


\section{Conflicts with other Economic Activities}

The beach environment is utilised for a number of other economic activities such as fisheries, coconut fibre, slaked lime, etc. and for the home of inhabitants. Therefore, tourist activity has come into conflict with an industry that competes with it for the use of coastal resources.

Firstly, there are instances of traditional access to the beach by fishermen being obstructed by the siting of hotels. Even when alternative paths were provided by hotelliers, fishermen have not been entirely pleased and have resorted to disruptive activities. Cases can be cited from Ahungalla, Kosgoda and Weligama in relation to individual hotel sites. Where cluster development has taken place this problem has not assumed serious proportions. The two industries, fishing and tourism, have interacted and coexisted with no serious problems between them.

Secondly, relocation of local people from coastal lands for tourism activities makes sociological and ethnological problems. There are a large number of temporary structures in the coastal land, which are actually residential homes of some for whom the sea is a means of livelihood. They are fisherman or coral miners. A large majority, most probably encroachers may, however, not have legal title to the land they occupy (Senevirathna, 1994). Some may have prescriptive titles after having been in occupation for over 10 years. In these cases, on the one hand, compulsory acquisition may be carried out under the Urban Development Authority Law, No. 41 of 1978, Part V, Section 15 and Section 16 (Government of Sri Lanka, 1978). Without resorting to compulsory acquisition, it is also possible for the UDA to declare any area as a 'Development Area' in terms of Section 23 of the UDA Law whereby all plans and projects applicable to the area shall cease to operate.

The relocation of these people as well as the fisherman has been so sensitive an issue politically those laws have proved ineffective. Fishermen particularly prefer the convenience of a seaside residence in order to carry their nets onto the beach. Areas in which intensive tourist development has already taken place are also difficult to relocate, but can be excluded from any further development. It is not found that any of the large and medium sized hotels already constructed with approval by several state authorities be demolished, as considerable private investment has gone into the plant.

Thirdly, coconut industry conflicts with land uses for tourism. The coconut lands in coastal areas are increasingly being converted to other uses. This resulted the agricultural land loss, increase in land prices, etc. Furthermore, as Senevirathna (1994) observes, the coconut fibre industry and the tourism industry are conflicting. The coconut fibre industry has traditionally used 
the coastal waters and lagoons on the coastal belt for the purpose of retying the coconut husks - a process which facilitates the extraction of fibre from the husk after it has been soaked in saline water for several days. A sizeable population in some coastal villages depend on this industry as a supplementary or principle source of income. The retying of coconut husks is carried out both for the sale of fibre and for producing the raw material for the cottage industry manufacturing coir ropes. There are several instances of village settlements having to be relocated to make way for the siting of beach hotels. The two activities cannot exist side by side as a strong unpleasant odour emanates from the coconut husk retying pits. Examples of such sites can be seen at Kosgoda, Dickwella and Weligama on the South Coast.

Fourthly, coral mining conflicts with the tourism industry. Coral mining has already been made illegal, but the activity still continues. The manufacturing of slaked lime by burning coral stone takes place on a large scale in the coastal zone. The lime is used for white-washing buildings and is in demand by the construction industry. Large scale mining of off-shore coral provides the raw material for the industry. Perhaps the most important tourist town where the activity takes place alongside tourism is Hikkaduwa. It was the beautiful undersea coral gardens and marine life that originally attracted tourists and tourist facilities into this town. On the one hand, this results coral mining community to loose their livelihood. On the other hand, coral mining activity depletes the beautiful undersea coral gardens and marine life that lured the tourist

Highly centralised land administration in the country is the main reason for land conflicts. The present system of administration and management of state lands is not satisfactory, due to lack of trained personnel, functional overlap among agencies. Land is a subject now coming under the purview of at least half the Cabinet Ministries and the Provincial Councils. Different agencies such as the Railways Department, Urban Development Authority, Ceylon Tourist Board, Forest Department or the Department of Wildlife have their own plans and agendas without adequate co-ordination. There have been numerous occasions when conflicts of interest have become obvious, even between different state agencies. For example, many tourism-related subjects such as coast, forest, wildlife and cultural heritage fall under separate departments. Any conflicts of interest between the Ministries have to be resolved at the Head of State level, often without the necessary scientific information. Community participation in decision making is minimal. This leads to lack of implementation, monitoring and evaluation of programmes.

\section{Conclusion}

The government of Sri Lanka has been able to provide land with other infrastructure for tourism facilities developers without much difficulty, as 
there are legal provisions to acquire private lands and state-owned lands. The country has substantial laws and regulations concerning environmental conservation and anti-pollution laws. Tourist product development, conservation, preservation and protection have been given a high priority from the inception of formal tourism, through land zoning. The zoning was designed to prevent uncontrolled development. Therefore it was expected that land use for tourism would not result in much conflicts in the prevailing land use system. The operation and implementation of those laws and regulations are, however, in its infancy and there are overlaps, loopholes and complex procedures.

Past experience of tourism development in Sri Lanka provides evidence of the serious neglect of those environmental resources that originally attracted tourists to Sri Lanka. Foremost among such resources is the coastal environment. The clearing of lands from traditional economic activities, and encroached lands for tourism activities, have sometimes made sociologically unpleasant situations. Some coastal areas have been zoned as no development or restricted development so as to preserve them from unsightly uncontrolled development. However, the conservation strategy, sometimes, is ineffective as discussed earlier. These suggest that coastal land use planning for tourism does not lead to sustainable development.

The strategy that is required to ensure the sustainable use of land resources is one that involves integrated land use planning with the active participation of the state agencies, private sector organisations and the local community. The ingredients that should make up the strategy include certain basic changes in tourism policy, tourism law, and priority ranking assigned to conservation.

\section{References}

Bandara, H. M (2000). A Critique of Tourism Development Planning in Developing Countries: The Case of Sri Lanka, Unpublished Ph.D. Thesis. Glasgow: The Scottish Hotel School, University of Strathclyde.

Broadly, E and Cunningham, R. (1994). Credit Geography. Scotland: C.B. Publishing Ltd.

Central Bank of Sri Lanka (2005). Review of the Economy. Colombo: Central Bank of Sri Lanka.

Ciriacy-Wantrup, S.V. (1971). The Economics of Environmental Policy, Land Economics, 47, pp 36-45. http://dx.doi.org/10.2307/3144965

Coast Conservation Department (1990). Coastal Zone Management Plan. Colombo: Sri Lanka Coast Conservation Department. 
Dieke, P.U.C. (1988). The Development of Tourism in Kenya and The Gambia - A Comparative Analysis, Unpublished PhD Thesis. Glasgow: The Scottish Hotel School, University of Strathclyde.

Government of Ceylon (1840). Encroachment upon Crown Lands Ordinance. Colombo: Government Press.

Government of Ceylon (1968). Tourist Development Act No 14 of 1968. Colombo: Government Press.

Government of Sri Lanka (1978). Urban Development Authority Law No 41 of 1978. Colombo: Government Press.

Government of Sri Lanka (1980). National Environmental Act No 47 of 1980. Colombo: Government Press.

Government of Sri Lanka (1987a). Land Commission report 1987. Colombo: Government Press.

Government of Sri Lanka (1987b). Tourist Development (Amendment) Act No 2 of 1987. Colombo: Government Press.

Gunton, T and Flynn, S. (1992). Resolving Environmental Conflicts: The Role of Mediation and Negotiation, Environments, 21, 3, pp 12-16

Harria, Kerr, Foster \& Co. (1967). Ceylon Tourist Plan. Honolulu, Hawaii: Harria, Kerr, Foster \& Co.

Jenkins, C. L. (1994). Tourism in Developing Countries: The Privatisation Issue, In A. V. Seaton, C. L. Jenkins, R. C. Wood, P. U. C. Dieke, M. M. Bennett, L. R. MacLellan, and R. Smith (eds.), Tourism: The State of the Art. Chichester: John Wiley. pp 3-9

Madduma Bandara, C. M. (1998). Land Use and Land Settlements: The Last Fifty Years and some Thoughts on Future Policy, in A.D.V.De Indrarathna (ed.), Fifty Years of Sri Lanka's Independence - A Socio-Economic Review. Colombo, Sri Lanka: Sri Lanka Institute of Social and Economic Studies. pp 72-85

McKercher, B. (1992). Tourism as a Conflicting Land Use, Annals of Tourism research. 19, pp 467-481 http://dx.doi.org/10.1016/0160-7383(92)901318

NARESA (1991). Natural Resources of Sri Lanka - Conditions and Trends. Colombo: The Natural Resources, Energy and Science Authority of Sri Lanka. 
Ranasingha, I. (1997). Effectiveness of Coastal Set-back Standards as a Nonstructural Solution for Managing Coastal Land in Sri Lanka, Paper read at Conference on Coastal and Ocean Management, Massachusetts, Boston, USA

Redclift, M. and Sage, C. (1996). Strategies for Sustainable Development. Chichester: John Wiley and Sons.

Samaranayake, H.M.S. (1998). Development of Tourism in Sri Lanka and Its Impact on the Economy and Society, in A.D.V. De Indrarathna (ed.), Fifty Years of Sri Lanka's Independence - A Socio-Economic Review. Colombo: Sri Lanka Institute of Social and Economic Studies. pp 292-310

Sarantakos, S. (1998). Social Research, (2 $2^{\text {nd }}$ Ed.). London: Mcmillan Press. http://dx.doi.org/10.1007/978-1-349-14884-4

Senevirathna, P. (1994). Tourism in Sri Lanka's Coastal Environment: Activities, Contributions, Conflicts and Projections, Coastal Resource Management Report, Sponsored by United States Agency for International Development and the Government of Sri Lanka (USAIDGSL), Colombo.

SLTDA (2011). Annual Statistical Report. Sri Lanka Tourism Development Authority. Colombo: SLTDA.

Somasekaram, T. (1997). Land Use, in T. Somasekaram, M. P. Perera, M. B. G. de Silva and H. Godellawatta (eds.), Arjuna's Atlas of Sri Lanka. Sri Lanka: Arjuna Consulting Co Ltd. pp 82-84

Strauss, A. and Corbin, J. (1998). Basics of Quantitative Research. London: SAGE Publications.

SSSA (1984). Land Use Planning Techniques and Policies. Madison, USA: Social Science Society of America.

UNDP/WTO (1993). Tourism Master Plan - Sri Lanka. Madrid: United Nations Development Programme and World Tourism Organisation.

Williums, P. W., Penrose, R. W. and Hawkes, S. (1998). Shared Decisionmaking in Tourism Land Use Planning, Annals of Tourism research, 25, 4, pp 860-889. http://dx.doi.org/10.1016/S0160-7383(98)00037-1 
